\title{
Response: Commentary: Deformation and Fault Propagation at the Lateral Termination of a Subduction Zone: The Alfeo Fault System in the Calabrian Arc, Southern Italy
}

\author{
Francesco Emanuele Maesano *, Mara Monica Tiberti and Roberto Basili \\ Istituto Nazionale di Geofisica e Vulcanologia, Roma, Italy
}

Keywords: lithospheric tear fault, seismic stratigraphy, Calabrian subduction, Ionian Sea, Italy, decoupling, fault propagation, Calabrian Arc

\section{A Commentary on}

Commentary: Deformation and Fault Propagation at the Lateral Termination of a Subduction Zone: The Alfeo Fault System in the Calabrian Arc, Southern Italy

OPEN ACCESS

Edited by: Alexander Cruden, Monash University, Melbourne, VIC, Australia

Reviewed by: Gideon Rosenbaum,

The University of Queensland, Brisbane, QLD, Australia

*Correspondence:

Francesco Emanuele Maesano francesco.maesano@ingv.it

Specialty section: This article was submitted to Structural Geology and Tectonics,

a section of the journal

Frontiers in Earth Science

Received: 21 December 2020 Accepted: 10 February 2021 Published: 22 March 2021

Citation:

Maesano FE, Tiberti MM and Basili R (2021) Response: Commentary: Deformation and Fault Propagation at the Lateral Termination of a

Subduction Zone: The Alfeo Fault System in the Calabrian Arc,

Southern Italy.

Front. Earth Sci. 9:644544. doi: 10.3389/feart.2021.644544

\section{INTRODUCTION}

Argnani (2020) raised concerns about our interpretation of the Alfeo Fault System (AFS) as a lithospheric tear bounding the Calabrian Arc (Maesano et al., 2020). Some of these concerns arise from elements overlooked by Argnani (2020); others are marginally related to our work; none of them implies possible changes in our results in the absence of newer data. We briefly discuss these issues in the following.

\section{PREVIOUS LITERATURE}

We confirm to have used an inappropriate citation concerning the assessment of the AFS as a main lithospheric tear; we should have cited Argnani and Bonazzi (2005) instead of Argnani et al. (2012).

Argnani and Bonazzi (2005) concluded that "the structural features [...] support the occurrence of a lithospheric tear between the ionian oceanic lithosphere and the continental lithosphere of the Hyblean plateau [...]. This lithospheric tear is responsible for the neotectonics of the region, that affects the eastern Sicily slope as far south as Siracusa, with the Malta Escarpment that acted as an inherited weakness zone." We confirm that our results contradict the above interpretation of the fault mapped by Argnani and Bonazzi (2005), which runs roughly N-S, dips only at c. $30^{\circ}$, and is very shallow with no evidence of deep rooting. The AFS instead is oriented NNW-SSE, very steep, and rooted within the Ionian oceanic crust. North of Siracusa, the AFS and the fault mapped by Argnani and Bonazzi (2005) are very close to each other; as already highlighted by Dellong et al. (2020b), this may explain the disagreement on the two faults. Argnani et al. (2012) adopted the faults proposed by Argnani and Bonazzi (2005), which caused the glitch of our inappropriate citation. 
Extrapolating from this inappropriate citation, Argnani (2020) claimed that we intentionally missed a large active extensional basin along the Malta Escarpment north of Siracusa. We firmly rebuke this allegation. Our Figure $8 \mathrm{~B}$ clearly shows the widespread Plio-Holocene basin to the west of the Calabrian Accretionary Wedge (CAW) front with a thickness greater than the SSTBs. This basin is even much bigger than what Argnani (2020; Figure 1) reported despite the available data to map it (Argnani and Bonazzi, 2005; Figure 3), as it extends from offshore Catania to the south of the Alfeo seamount. We interpreted the growth strata in this basin as resulting from salt tectonics at the CAW toe (our Figure 5A; see also Maesano et al., 2017) and not to the activity of normal faults.

\section{NORTHERN EXTENT OF ALFEO FAULT SYSTEM}

The Tindari-Taormina Fault (TTF) was outside the study area of our work, and we have not analyzed any direct data concerning it. We thus mentioned works by others (Introduction) and only noted that the TTF offshore prolongation (southern end) shares the same approximate strike and map position with fault F4 (northern end). We thus marked the TTF and faults F1-F4 with different line styles in Figure 7A. In the 3D diagram (Figure 10), we showed that the TTF (represented by a dashed line) only affects the upper plate in agreement with our previous work on the Calabrian Arc (Maesano et al., 2017).

\section{SHALLOW SYN-TECTONIC BASINS AND AGE ATTRIBUTION}

Regarding the genetic relationship between the AFS and the Shallow Syn-Tectonic Basins (SSTBs) development and age, any well-grounded different interpretation is always welcome, but Argnani (2020) neither proposed a different explanation nor provided evidence to challenge our interpretation. We proposed a mechanism entirely based on a data-driven geometric reconstruction that relates shallow brittle features to deepseated major faults (F1-F4), also supported by analog models (Bonini et al., 2015; Bonini et al., 2016). In the absence of any direct age determination, we assumed that all the AFS segments had a coeval activation below the widespread SSTBs (our Figure $8 \mathrm{~B}$ ). The basins coalescent geometry in the northern part hints at the contemporaneous activity of F2-F4 underneath, whereas the progressively reduced thickness of the elongated basin in the southern part hints at a progressively reduced accommodation space created by F1. Our Figure 9B clearly shows the dragging of unit U1a near the shallow secondary fault that is the early syncline effect, likewise similar features found in all the other profiles. We maintain that the online version of our Figure 5 is of high-enough resolution to support the interpretation of the SSTBs younger age in profile E relative to profile A.
We did not use sediment compaction to discuss the estimates of the AFS activity rates because the absence of calibration data in the area would have led to unreliable results; otherwise, the details of that procedure would have been provided (e.g., Maesano et al., 2013; Maesano et al., 2015; Maesano and D’Ambrogi, 2016). We repeatedly cautioned the readers about the need to consider the inferred throw-rates as minimum estimates.

\section{SUPPOSED UNDER-EXPLORED TECTONIC ISSUES}

The supposed differences between our interpretation and the work by Dellong et al. (2018) are specious because the two works, in reality, complement each other. The refraction profiles by Dellong et al. (2018) and Dellong et al. (2020a) have a resolution that captures large-scale features, whereas our data resolution permits focusing on the fault zone complexity. Similarly, we used the data at higher resolution by Gutscher et al. (2016) for aiding the interpretation of the shallower part of the structure. Overall, our interpretation is a novel contribution that complements the interpretations proposed by Gutscher et al. (2016), Gutscher et al. (2017), Dellong et al. (2018), Dellong et al. (2020a) and confirmed by Dellong et al. (2020b).

On a different note, instead, is the occurrence of serpentinite diapirs discussed by Polonia et al. (2017), which were well acknowledged in our work. We reported the diapir positions in Figure 8 to help interpret the sediment thickness variations. However, further analyses about these diapirs were beyond our scope, and the topic remains open for future work.

We remark that there are certainly under-explored aspects in our study like there always are in any study. Our work focused on a few AFS specific aspects, not on making its ultimate review.

\section{NATURAL HAZARD IMPLICATIONS}

Finally, Argnani (2020) stated that the AFS "has little if any capability to generate tsunamis." without providing any physical basis for this assessment. Indeed, the decoupling of the deep AFS from the faults bounding the SSTBs can hardly be a reason. If one applies the seismic parameterization of Argnani et al. (2012) to the AFS obtains comparable tsunami amplitudes both in the near- and the far-field of the source (Basili et al., 2020). The topic, however, is marginally related to this discussion because we did not tackle the reconstruction of the January 11, 1693 earthquake and tsunami, which is the subject of a long-lasting debate (Piatanesi and Tinti, 1998; Tinti et al., 2001; Gutscher et al., 2006; Visini et al., 2009; Pirrotta and Barbano, 2020).

\section{FINAL REMARKS}

This commentary touched just a few aspects of an offshore fault system, the AFS, that gained attention only in the last decade. The 
AFS role as the Calabrian Arc lateral termination has already been preferred among older and recent alternative views (Gutscher et al., 2017). Hopefully, this exchange will stimulate future indepth studies to shed light on the seismotectonics of this particular corner of the central Mediterranean and further explore the tectonic implications of these recent findings.

\section{AUTHOR CONTRIBUTIONS}

All authors listed have made a substantial, direct, and intellectual contribution to the work and approved it for publication.

\section{REFERENCES}

Argnani, A. (2020). Commentary: deformation and fault propagation at the lateral termination of a subduction zone: the Alfeo Fault system in the calabrian Arc, southern Italy. Front. Earth Sci. 8, 602506. doi:10.3389/feart.2020.602506

Argnani, A., Armigliato, A., Pagnoni, G., Zaniboni, F., Tinti, S., and Bonazzi, C. (2012). Active tectonics along the submarine slope of south-eastern Sicily and the source of the 11 January 1693 earthquake and tsunami. Nat. Hazards Earth Syst. Sci. 12, 1311-1319. doi:10.5194/nhess-12-1311-2012

Argnani, A., and Bonazzi, C. (2005). Malta Escarpment fault zone offshore eastern Sicily: pliocene-quaternary tectonic evolution based on new multichannel seismic data. Tectonics 24. doi:10.1029/2004tc001656

Basili, R., Volpe, M., Maesano, F. E., and Tiberti, M. M. (2020). Comparing the tsunamigenic potential of two alternative earthquake rupture scenarios in the Ionian Sea. Roma: Istituto Nazionale di Geofisica e Vulcanologia (INGV), 8. doi:10.5281/zenodo.4353092

Bonini, L., Basili, R., Toscani, G., Burrato, P., Seno, S., and Valensise, G. (2015). The role of pre-existing discontinuities in the development of extensional faults: an analog modeling perspective. J. Struct. Geol. 74, 145-158. doi:10.1016/j.jsg.2015. 03.004

Bonini, L., Basili, R., Toscani, G., Burrato, P., Seno, S., and Valensise, G. (2016). The effects of pre-existing discontinuities on the surface expression of normal faults: insights from wet-clay analog modeling. Tectonophysics 684, 157-175. doi:10. 1016/j.tecto.2015.12.015

Dellong, D., Klingelhoefer, F., Dannowski, A., Kopp, H., Murphy, S., Graindorge, D., et al. (2020a). Geometry of the deep calabrian subduction (central mediterranean sea) from wide-angle seismic data and 3-D gravity modeling. Geochem. Geophys. Geosyst. 21, 2019GC008586. doi:10.1029/2019GC008586

Dellong, D., Klingelhoefer, F., Dannowski, A., Kopp, H., Murphy, S., Graindorge, D., et al. (2020b). Reply to comment by A. Argnani on "geometry of the deep calabrian subduction from wide-angle seismic data and 3-D gravity modeling". Geochem. Geophys. Geosyst. 21, e09223. doi:10.1029/2020GC009223

Dellong, D., Klingelhoefer, F., Kopp, H., Graindorge, D., Margheriti, L., Moretti, M., et al. (2018). Crustal structure of the ionian basin and eastern sicily margin: results from a wide-angle seismic survey. J. Geophys. Res. Solid Earth 123, 2090-2114. doi:10.1002/2017JB015312

Gutscher, M.-A., Dominguez, S., de Lepinay, B. M., Pinheiro, L., Gallais, F., Babonneau, N., et al. (2016). Tectonic expression of an active slab tear from high-resolution seismic and bathymetric data offshore Sicily (Ionian Sea). Tectonics 35, 39-54. doi:10.1002/2015TC003898

Gutscher, M.-A., Kopp, H., Krastel, S., Bohrmann, G., Garlan, T., Zaragosi, S., et al. (2017). Active tectonics of the Calabrian subduction revealed by new multi-beam bathymetric data and high-resolution seismic profiles in the Ionian Sea (Central Mediterranean). Earth Planet. Sci. Lett. 461, 61-72. doi:10.1016/j.epsl.2016.12.020

Gutscher, M.-A., Roger, J., Baptista, M.-A., Miranda, J. M., and Tinti, S. (2006). Source of the 1693 Catania earthquake and tsunami (Southern Italy): new

\section{FUNDING}

This work received financial support from the TSUMAPS-NEAM Project, co-financed by the European Union Civil Protection Mechanism, Agreement Number: ECHO/SUB/2015/718,568/ PREV26.

\section{ACKNOWLEDGMENTS}

We thank V. Kastelic and U. Fracassi for their comments and suggestions of an earlier version of this reply.

evidence from tsunami modeling of a locked subduction fault plane. Geophys. Res. Lett. 33, L08309. doi:10.1029/2005GL025442

Maesano, F. E., and D'Ambrogi, C. (2016). Coupling sedimentation and tectonic control: pleistocene evolution of the central Po Basin. IJG 135, 394. doi:10.3301/ IJG.2015.17

Maesano, F. E., D’Ambrogi, C., Burrato, P., and Toscani, G. (2015). Slip-rates of blind thrusts in slow deforming areas: examples from the Po Plain (Italy). Tectonophysics 643, 8-25. doi:10.1016/j.tecto.2014.12.007

Maesano, F. E., Tiberti, M. M., and Basili, R. (2017). The Calabrian Arc: threedimensional modelling of the subduction interface. Sci. Rep. 7, 8887. doi:10. 1038/s41598-017-09074-8

Maesano, F. E., Tiberti, M. M., and Basili, R. (2020). Deformation and fault propagation at the lateral termination of a subduction zone: the Alfeo Fault system in the Calabrian Arc, southern Italy. Front. Earth Sci. 8, 107. doi:10. 3389/feart.2020.00107

Maesano, F. E., Toscani, G., Burrato, P., Mirabella, F., D’Ambrogi, C., and Basili, R. (2013). Deriving thrust fault slip rates from geological modeling: examples from the Marche coastal and offshore contraction belt, Northern Apennines, Italy. Mar. Pet. Geol. 42, 122-134. doi:10.1016/j.marpetgeo. 2012.10.008

Piatanesi, A., and Tinti, S. (1998). A revision of the 1693 eastern Sicily earthquake and tsunami. J. Geophys. Res. 103, 2749-2758. doi:10.1029/97JB03403

Pirrotta, C., and Barbano, M. S. (2020). New macroseismic and morphotectonic constraints to infer a Fault model for the 9 (Mw6.1) and 11 january (Mw7.3) 1693 earthquakes (Southeastern Sicily). Front. Earth Sci. 8, 550851. doi:10.3389/ feart.2020.550851

Polonia, A., Torelli, L., Gasperini, L., Cocchi, L., Muccini, F., Bonatti, E., et al. (2017). Lower plate serpentinite diapirism in the Calabrian Arc subduction complex. Nat. Commun. 8, 2172. doi:10.1038/s41467-017-02273-x

Tinti, S., Armigliato, A., and Bortolucci, E. (2001). Contribution of tsunami data analysis to constrain the seismic source: the case of the 1693 eastern Sicily earthquake. J. Seismol. 5, 41-61. doi:10.1023/A:1009817601760

Visini, F., De Nardis, R., Barbano, M. S., and Lavecchia, G. (2009). Testing the seismogenic sources of the January 11th 1693 Sicilian earthquake (Io X/XI): insights from macroseismic field simulations. Ital. J. Geosci. 128 (1), 147-156.

Conflict of Interest: The authors declare that the research was conducted in the absence of any commercial or financial relationships that could be construed as a potential conflict of interest.

Copyright (c) 2021 Maesano, Tiberti and Basili. This is an open-access article distributed under the terms of the Creative Commons Attribution License (CC $B Y)$. The use, distribution or reproduction in other forums is permitted, provided the original author(s) and the copyright owner(s) are credited and that the original publication in this journal is cited, in accordance with accepted academic practice. No use, distribution or reproduction is permitted which does not comply with these terms. 